\title{
Northern peatland carbon stocks and dynamics: a review
}

\author{
Z. C. Yu
}

Department of Earth and Environmental Sciences, Lehigh University, 1 West Packer Avenue, Bethlehem, PA 18015, USA

Correspondence to: Z. C. Yu (ziy2@lehigh.edu)

Received: 15 March 2012 - Published in Biogeosciences Discuss.: 26 April 2012

Revised: 13 September 2012 - Accepted: 24 September 2012 - Published: 22 October 2012

\begin{abstract}
Peatlands contain a large belowground carbon (C) stock in the biosphere, and their dynamics have important implications for the global carbon cycle. However, there are still large uncertainties in $\mathrm{C}$ stock estimates and poor understanding of $\mathrm{C}$ dynamics across timescales. Here I review different approaches and associated uncertainties of $\mathrm{C}$ stock estimates in the literature, and on the basis of the literature review my best estimate of $\mathrm{C}$ stocks and uncertainty is $500 \pm 100$ (approximate range) gigatons of $\mathrm{C}(\mathrm{GtC}$ ) in northern peatlands. The greatest source of uncertainty for all the approaches is the lack or insufficient representation of data, including depth, bulk density and carbon accumulation data, especially from the world's large peatlands. Several ways to improve estimates of peat carbon stocks are also discussed in this paper, including the estimates of $\mathrm{C}$ stocks by regions and further utilizations of widely available basal peat ages.

Changes in peatland carbon stocks over time, estimated using Sphagnum (peat moss) spore data and down-core peat accumulation records, show different patterns during the Holocene, and I argue that spore-based approach underestimates the abundance of peatlands in their early histories. Considering long-term peat decomposition using peat accumulation data allows estimates of net carbon sequestration rates by peatlands, or net (ecosystem) carbon balance (NECB), which indicates more than half of peat carbon ( $>270 \mathrm{GtC}$ ) was sequestrated before $7000 \mathrm{yr}$ ago during the Holocene. Contemporary carbon flux studies at 5 peatland sites show much larger NECB during the last decade ( $32 \pm 7.8$ (S.E.) $\mathrm{g} \mathrm{C} \mathrm{m}^{-2} \mathrm{yr}^{-1}$ ) than during the last $7000 \mathrm{yr}$ $\left(\sim 11 \mathrm{~g} \mathrm{C} \mathrm{m}^{-2} \mathrm{yr}^{-1}\right)$, as modeled from peat records across northern peatlands. This discrepancy highlights the urgent need for carbon accumulation data and process understanding, especially at decadal and centennial timescales, that would bridge current knowledge gaps and facilitate comparisons of NECB across all timescales.
\end{abstract}

\section{Introduction}

Northern peatlands developed mostly after the last deglaciation in the circum-Arctic region and represent one of the largest carbon pools in the biosphere. Their dynamics have played an important role in the global carbon cycle during the Holocene (Gorham, 1991; Yu, 2011), and it has become essential to include peatlands in the modeling and analysis of the global carbon cycle to constrain the changes in other carbon reservoirs (Brovkin et al., 2002; Kleinen et al., 2010; Menviel and Joos, 2012) and in the discussion of relative roles of anthropogenic and natural processes (Ruddiman et al., 2011). However, there are very different estimates of peat carbon stocks in the literature (e.g., Gorham, 1991; Turunen et al., 2002). Also, little is known about the sequestration history of peatland carbon stocks. Documenting and understanding the total carbon stocks and their accumulation histories will help project and understand possible surprise and changes of peatlands in the future (Moore, 2002; Frolking et al., 2011; Yu et al., 2011).

Here I provide a brief review of published estimates of carbon stocks, their accumulation histories, and comparison of contemporary and paleo carbon fluxes from northern (boreal and subarctic, or circum-Arctic) peatlands. Below in Sect. 2, I present an assessment of approaches, estimates, and uncertainties of carbon stocks. Although the focus of this review is on northern peatlands as a whole, I also comment on some studies with detailed regional analysis of carbon stocks, including Western Canada (including Mackenzie River Basin), Finland and West Siberia. Section 3 discusses peatland changes over time, where I review studies using basal peat ages for peatland initiation histories, synthesis of carbon accumulation rates, and histories of carbon stocks and modeled net (ecosystem) carbon balance (NECB). In Sect. 4, I discuss and compare the peat-core derived Holocene carbon 
sequestration rates with contemporary NECB from several peatland carbon flux sites and emphasize the lack of data and understanding of peatland carbon dynamics at decadal and centennial timescales. In the last Sect. 5, I highlight some future research directions and activities that will facilitate the understanding of peatland carbon dynamics.

\section{Total carbon stocks in northern peatlands}

\subsection{Approaches}

Three approaches have been used to estimate carbon stocks in peatlands: peat volume, carbon density and time history approaches (Table 1). All these approaches require information on present peatland area. The peat volume approach focuses on estimates of mean peat depth in order to derive the total peat volume (along with peatland area), and then uses bulk density and carbon proportion (carbon concentration) data to convert volume to mass and carbon (e.g., Gorham, 1991). The carbon density approach requires similar data, but focuses on estimating total carbon content of unit area (that is, soil carbon density) and then derives total carbon stocks by multiplying peatland area and soil carbon density (Armentano and Menges, 1986). This is a commonly used approach, also called "paint-by-number" approach, to empirically estimate carbon stocks of other ecosystem types (biomes) and of terrestrial biosphere as a whole (Schlesinger, 1977). Bulk density and carbon concentration data are derived from peat/soil profiles (pedons) to certain depth (oftentimes the top $1 \mathrm{~m}$ ) to calculate carbon density. The time history approach relies on data from carbon accumulation rates (carbon accumulated in unit area per year as derived from individual peat cores) and peatland areas over time to first calculate carbon stocks at each time interval and then sum up all time intervals for total carbon stocks. The time history approach is the only approach explicitly using multiple ages from individual peatlands (Yu et al., 2010), though Turunen et al. (2002) used mean peat ages for extrapolation of Finnish data to northern peatlands (see below).

All these approaches can be first applied to a peatland region or a type of peatland region, and then sum up data from different peatland types and regions for the total carbon stocks. However, oftentimes due to lack of detailed regional data many studies lumped all regions together for a single estimate of carbon stocks in northern peatlands. For example, Gorham (1991) used area-weighted depth and bulk density data from different major peatland regions to estimate a single mean peat depth and average bulk density for estimating total carbon stocks of northern peatlands using the peat volume approach. In the applications of the carbon density approach, most studies used a single value for carbon density (e.g., Schlesinger, 1977; Lappalainen, 1996), while Armentano and Menges (1986) estimated carbon density values for peatlands in different regions and then summed up for all northern peatlands. Yu et al. (2010) only presented a single estimate of carbon stocks and history using average accumulation rates and peatland area change at every 1000-yr interval over the Holocene for the entire northern peatlands. Table 1 shows the equations used in different approaches, the required data, and examples from the literature.

\subsection{Carbon stock estimates and uncertainties}

Several peatland carbon stock estimates have been published using the peat volume approach. Sjörs (1980) provided one of the first estimates of peatland carbon stocks using highly rounded and approximate values for peatland area, depth and bulk density. Sjörs (1980) estimated carbon stocks of $300 \mathrm{GtC}$ (gigatons of carbon) in northern peatlands (Table 2). Gorham's (1991) estimate of $455 \mathrm{GtC}$ is the most widely cited figure for carbon stocks in northern peatlands. This estimate is more than double the estimate made a year earlier by the same author (Gorham, 1990), mostly owing to the use of the revised and higher values for mean depth of $2.3 \mathrm{~m}$ and bulk density of $0.112 \mathrm{~g} \mathrm{~cm}^{-3}$ in Gorham (1991). On the basis of the detailed peatland inventory data from Finland (Mäkilä, 1994), Turunen et al. (2002) indicated that the mean depth and bulk density values used by Gorham (1991) were too high, and they estimated a total carbon stock of 270-370 Gt C in northern peatlands by extrapolating Finnish data. However, peatlands in Finland only represent a carbon stock of $2.3 \mathrm{GtC}$ - it is much too small a peatland region to be representative of the entire northern peatlands. Bulk density values from other large peatland regions are higher than the mean bulk density of $0.078-0.091 \mathrm{~g} \mathrm{~cm}^{-3}$ from Finland (Mäkilä, 1994; Turunen et al., 2002). For example, in continental western Canada a large database of 2167 peat samples from 120 peatland sites suggests a mean bulk density of $0.093 \mathrm{~g} \mathrm{~cm}^{-3}$ (Zoltai et al., 2000; Beilman et al., 2008), while Vitt et al. (2000) reported bulk density values of $0.094 \mathrm{~g} \mathrm{~cm}^{-3}$ for open fens and of $0.105 \mathrm{~g} \mathrm{~cm}^{-3}$ for wooded and shrubby fens. A summary of detailed peat-core analysis data from 14 cores at 12 sites in continental western Canada shows a mean bulk density value of $0.122 \mathrm{~g} \mathrm{~cm}^{-3}$ (ranges from 0.068 to $0.176 \mathrm{~g} \mathrm{~cm}^{-3}$ ) (Yu, 2006). Also, recent estimates of mean peat depths in some large peatland regions seem to be similar to the mean depth of $2.3 \mathrm{~m}$ used by Gorham (1991). For example, Riley (2011) reported mean peat depths from 1.88 to $2.55 \mathrm{~m}$ for bogs and from 1.37 to $2.15 \mathrm{~m}$ for fens from the south to north in the Ontario Hudson Bay Lowlands, similar to his earlier estimate of overall mean depth of $2.2 \mathrm{~m}$ (Riley, 1994). The Mackenzie River Basin of northern Canada (overlapping with part of continental western Canada), the second largest peatland complex in North America representing a total carbon stock of $13-18 \mathrm{Gt} \mathrm{C}$, has an overall mean depth of $2.22 \mathrm{~m}$ (Vitt et al., 2005). In a detailed spatial analysis of peatlands in the southern Mackenzie River Basin, Beilman et al. (2008) reported a mean peat depth of $2.5 \mathrm{~m}$ (ranging from 0.5 to $6 \mathrm{~m}$ ). Also, mean peat 
Table 1. General equations of different approaches for estimating peatland carbon stocks.

\begin{tabular}{|c|c|c|c|}
\hline Approach & Equation & Example & Note \\
\hline Peat volume approach & $C_{\text {peat }}=\sum_{i}\left(A_{i} \times \overline{D_{i}} \times \overline{B D_{i}} \times \overline{C C_{i}}\right)$ & $\begin{array}{l}\text { Vitt et al. (2000); Turunen } \\
\text { et al. (2002); and Sheng et } \\
\text { al. (2004) for regional C stock } \\
\text { estimates }\end{array}$ & $\begin{array}{l}\text { Sjör (1980) and Gorham (1990, } \\
\text { 1991) used one set of values for } \\
\text { all northern peatlands (that is, } \\
\text { a special case when } i=1)\end{array}$ \\
\hline Carbon density approach & $C_{\text {peat }}=\sum_{i}\left(A_{i} \times \overline{C D_{i}}\right)$ & $\begin{array}{l}\text { Armentano and Menges (1986) } \\
\text { (for different peatland regions); } \\
\text { Bridgham et al. (2006) (for } \\
\text { different types of wetlands, } \\
\text { including peatlands, in North } \\
\text { America) }\end{array}$ & $\begin{array}{l}\text { Schlesinger (1977) and } \\
\text { Lappalainen (1996) for all } \\
\text { peatlands when } i=1\end{array}$ \\
\hline Time history approach & $C_{\text {peat }}=\sum_{j}\left(A_{j} \times \overline{C R_{j}}\right)$ & Yu et al. (2010) & $\begin{array}{l}\text { Yu et al. (2010) used } \\
1000-y r \text { bins for calculating } \\
\text { C rates (CR) and C stocks }\end{array}$ \\
\hline
\end{tabular}

Notes: $C_{\text {peat }}$ : peat carbon stocks; $i$ : peatland region, or peatland type; $j:$ time period; $A_{i}$ or $A_{j}:$ peatland area in region $i$, for peatland type $i$, or during time period $j ; \overline{D_{i}}:$ mean peat depth for peatland region or type $i ; \overline{B D_{i}}$ : mean peat bulk density for peatland region or type $i ; \overline{C C_{i}}$ : mean carbon content for peatland region or type $i$; $\overline{C D_{i}}$ : carbon density for peatland region or type $i$; $\overline{C R_{j}}$ : mean carbon (accumulation) rates during the time period $j$.

Table 2. Estimates of northern peatland carbon stocks by different authors.

\begin{tabular}{|c|c|c|c|c|c|c|c|c|c|c|c|}
\hline$\#$ & Authors & Year & $\begin{array}{r}\text { Area } \\
\text { used } \\
\left(\times 10^{6}\right. \\
\left.\mathrm{km}^{2}\right)\end{array}$ & $\begin{array}{r}\text { Depth } \\
(\mathrm{m})\end{array}$ & $\begin{array}{r}\text { Bulk } \\
\text { density } \\
\left(\mathrm{g} \mathrm{cm}^{-3}\right)\end{array}$ & $\begin{array}{r}\text { Carbon } \\
\text { proportion }\end{array}$ & $\begin{array}{r}\text { Carbon } \\
\text { density } \\
\left(\mathrm{kgC} \mathrm{m}^{-2}\right)\end{array}$ & $\begin{array}{r}\text { Basal } \\
\text { ages } \\
\text { (cal years } \\
\mathrm{BP} \text { ) }\end{array}$ & $\begin{array}{r}\text { Carbon } \\
\text { accumulation } \\
\text { rates } \\
\left(\mathrm{g} \mathrm{C} \mathrm{m}^{-2} \mathrm{yr}^{-1}\right)\end{array}$ & $\begin{array}{r}\text { Carbon } \\
\text { stock } \\
(\mathrm{GtC}) \\
\text { (range) }\end{array}$ & Note \\
\hline \multicolumn{12}{|c|}{ Peat volume approach } \\
\hline 1 & Sjörs & 1980 & 4 & $>1$ & $>0.1$ & 0.5 & & & & 300 & $\begin{array}{l}\text { The estimate is not } \\
\text { different from Sjörs } \\
\text { (1981) }\end{array}$ \\
\hline 2 & Gorham & 1990 & 3.84 & $1.13-1.74$ & 0.0784 & 0.528 & & & & $180-227$ & \\
\hline 3 & Gorham & 1991 & 3.42 & 2.3 & 0.112 & 0.517 & & & & 455 & $\begin{array}{l}\text { Based on data from } \\
\text { former USSR, Canada, } \\
\text { USA } \\
\text { and Fennoscandia }\end{array}$ \\
\hline 4 & Turunen et al. & 2002 & 3.46 & 1.1 & $0.081-0.091$ & 0.5 & & 4200 & 18.5 & $270-370$ & $\begin{array}{l}\text { Estimates for northern } \\
\text { peatlands were extrapo- } \\
\text { lated from Finnish data } \\
\text { shown here }\end{array}$ \\
\hline \multicolumn{12}{|c|}{ Carbon density approach } \\
\hline 5 & Schlesinger & 1977 & 2 & & & & 68.8 & & & 137 & Top $1 \mathrm{~m}$ peat \\
\hline 6 & Post et al. & 1982 & 2.8 & & & & 72.3 & & & 202 & $\begin{array}{l}\text { Top } 1 \mathrm{~m} \text { peat; data } \\
\text { were from Schlesinger } \\
(1984)\end{array}$ \\
\hline 7 & Armentano and Menges & 1986 & 3.49 & 1 & $0.147(0.12-0.29)$ & 0.5 & 73.4 & & & 256 & $\begin{array}{l}\text { Top } 1 \mathrm{~m} \text { peat; area- } \\
\text { weighted bulk density, } \\
\mathrm{C} \text { density and total } \mathrm{C} \\
\text { pools are calculated } \\
\text { from their Table } 1 \text {; } \\
\text { carbon proportion is } \\
\text { assumed }\end{array}$ \\
\hline 8 & Oechel & 1989 & 1.1 & & & & 113.6 & & & 125 & $\begin{array}{l}\text { Only for boreal } \\
\text { peatlands }\end{array}$ \\
\hline 9 & Lappalainen & 1996 & 3.985 & & & & $58.7-63$ & & & $234-252$ & $\begin{array}{l}\text { Global peatlands for } \mathrm{C} \\
\text { stocks, but area for } \\
\text { northern peatlands }\end{array}$ \\
\hline 10 & Adams and Faure & 1998 & 2.43 & & & & 2 for biomass & & & 466 & $\begin{array}{l}\text { Assuming } 46 \mathrm{Gt} \mathrm{C} \\
\text { increase per kyr in } \\
\text { the Holocene }\end{array}$ \\
\hline \multicolumn{12}{|c|}{ Time history approach } \\
\hline 11 & Yu et al. & 2010 & 4 & & & & & 7300 & 18.6 & $473-621$ & $\begin{array}{l}\text { Age was for the mean } \\
\text { basal age (as in Yu, } \\
\text { 2011), not necessarily } \\
\text { the mean age of peat } \\
\text { deposits }\end{array}$ \\
\hline
\end{tabular}


depth in West Siberia (the largest peatland basin in the world) is more than $2 \mathrm{~m}$ (Sheng et al., 2004). All these recent depth estimates from these large peatland regions are much deeper than Finnish peatlands of $1.1 \mathrm{~m}$ used in Turunen et al. (2002). These regions also contain much larger carbon stocks (Table 3), $16 \mathrm{GtC}$ in the Mackenzie River Basin (Vitt et al., 2005), $48 \mathrm{GtC}$ in continental western Canada (Vitt et al., 2000), and 70.2 GtC in West Siberian Lowlands (Sheng et al., 2004). Thus, very likely the estimate of $270-370 \mathrm{Gt} \mathrm{C}$ in carbon stocks of northern peatlands by Turunen et al. (2002) is an underestimate.

As indicated above, the carbon density approach is one of the common approaches used for scaling up carbon stocks for different biomes based on the average or representative carbon density value. Carbon stock estimates for wetlands or peatlands were often done as part of global soils or ecosystem carbon stock estimates (Schlesinger, 1977; Post et al., 1982; Adams and Faure, 1998). Also, most of the available global soil survey data are for the top $1 \mathrm{~m}$ of soil carbon density (e.g., GSDTG, 2000), so this often results in significant underestimates of carbon density and total carbon stocks (Table 2). The estimation of carbon stocks of 234-252 Gt C estimated by Lappalainen (1996) is one of the most recent estimates using the carbon density approach in a study focusing only on peatlands, but it is surprisingly low, likely due to the very low soil carbon density value $\left(58.7-63 \mathrm{~kg} \mathrm{C} \mathrm{m}^{-2}\right)$ used by Lappalainen (1996), which is even lower than the ones only for the top $1 \mathrm{~m}$ soils/peat in other studies using the carbon density approach (Table 2). Another factor for very low estimates in most studies using the carbon density approach is the small peatland area used (e.g., Schlesinger, 1977; Post et al., 1982; Oechel, 1989). The estimate of $466 \mathrm{GtC}$ by Adams and Faure (1998) is not really an estimate using the carbon density approach (they only indicated a vegetation biomass carbon density of $2 \mathrm{~kg} \mathrm{C} \mathrm{m}^{-2}$ ), but they used an assumed rate of peat carbon stock buildup at $46 \mathrm{GtC} \mathrm{kyr}^{-1}$ since the beginning of the Holocene. Another estimate for only part of the peatland domain is from soil survey (pedon/soil profile) data for circum-Arctic permafrost regions by Tarnocai et al. (2009), which estimated carbon stocks of $280 \mathrm{GtC}$ in peatlands of permafrost regions.

The time history approach relies on peatland development histories to estimate total carbon stocks during the Holocene and beyond. Yu et al. (2010) provided a first estimate of peatland carbon stocks using dated carbon accumulation records and the peatland area change over time as derived from basal ages. They calculated mean carbon accumulation rates for each 1000-yr bin during the Holocene from 33 dated peat profiles across northern peatlands (Fig. 1c; Yu et al., 2009). Also, they derived a first approximation of peatland area change over time at 1000-yr intervals (Fig. 1b) using the 1516 basal peat ages across the northern peatland domain (Fig. 1a; MacDonald et al., 2006), under the assumption that the expansion rates of individual peatlands were constant, or peatland area has increased linearly, since their peatland

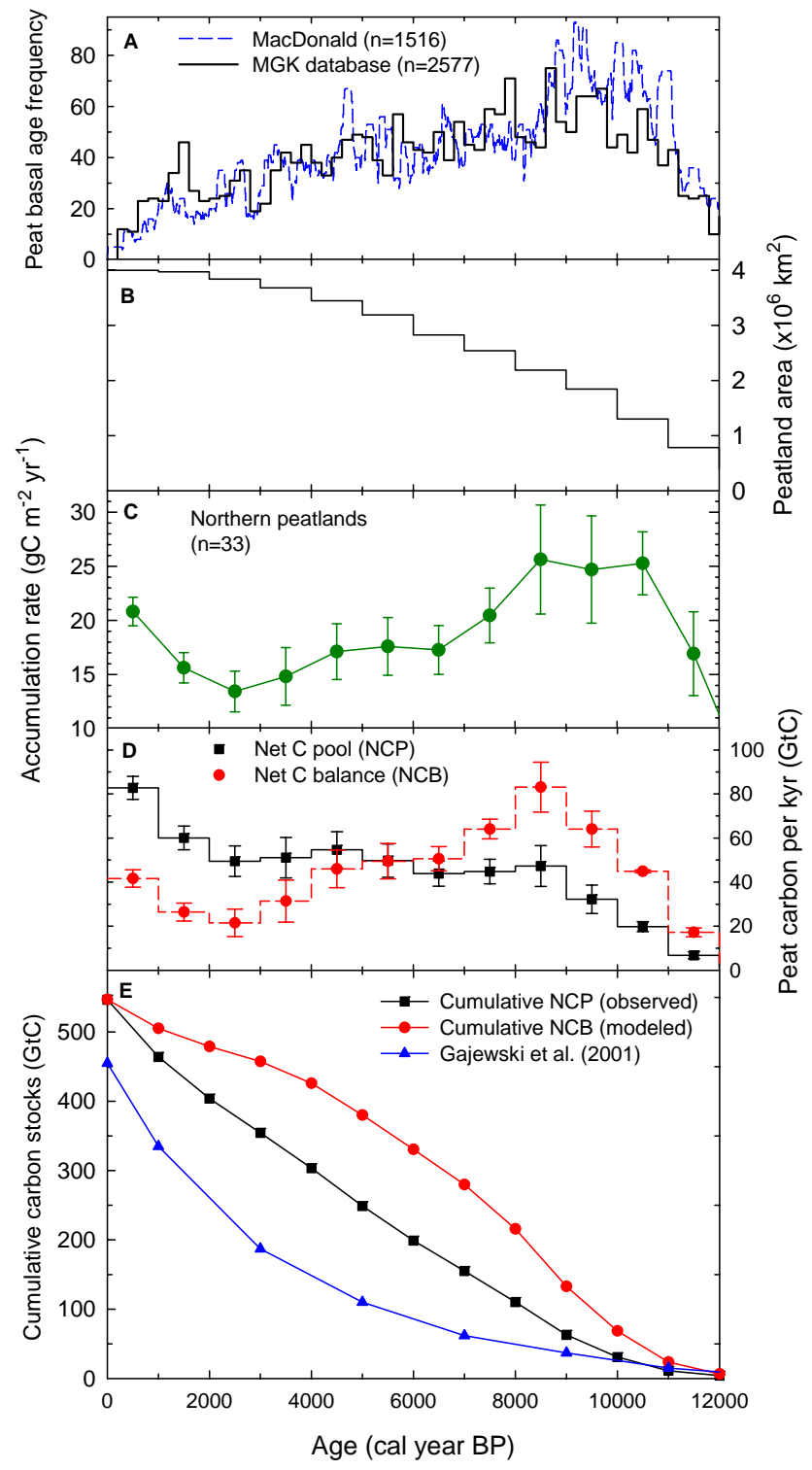

Fig. 1. Peatland change over time during the Holocene. (A) Basal ages and peatland initiation histories (dashed line $(n=1516)$ : MacDonald et al. 2006; solid line (2577): combined datasets from MacDonald et al., 2006; Gorham et al., 2007; and Korhola et al., 2010 as in Yu et al., 2012b); (B) peatland area change at 1000-yr intervals over time estimated from cumulative basal age histogram as in (A) (MacDonald et al., 2006) and the present peatland area of $4 \times 10^{6} \mathrm{~km}^{2}$ (Yu, 2011); (C) carbon accumulation rates based on 33 sites across northern peatlands with error bars from standard errors of the means (Yu et al., 2009); (D) observed net carbon pool (NCP) and modeled net carbon balance (NCB) for northern peatlands at 1000-yr intervals, with standard errors as error bars (Yu et al., 2010; Yu, 2011); (E) cumulative peatland carbon stocks from NCP (squares; Yu et al., 2010), NCB (circles), and from scaling the carbon stocks of Gorham (1991) using Sphagnum-spore data (Gajewski et al., 2001). 
Table 3. Estimates of carbon stocks in peatlands of different regions.

\begin{tabular}{|c|c|c|c|}
\hline$\#$ & Region & $\begin{array}{r}\mathrm{C} \text { stock in } \\
\text { peatlands } \\
(\mathrm{Gt} \mathrm{C})\end{array}$ & Reference \\
\hline 1 & North America & 178 & Bridgham et al. (2006) \\
\hline 2 & Canada & 150 & Tarnocai et al. (2005) \\
\hline 3 & Alaska & 15.5 & Bridgham et al. (2006) \\
\hline 4 & $\begin{array}{l}\text { Continental western } \\
\text { Canada (Provinces of } \\
\text { Alberta, Saskatchewan, } \\
\text { and Manitoba) }\end{array}$ & 48 & Vitt et al. (2000) \\
\hline 5 & Mackenzie River Basin & 16 & Vitt et al. (2005) \\
\hline 6 & Finland & 2.3 & Turunen et al. (2002) \\
\hline 7 & Russia & 214 & Botch et al. (1995) \\
\hline 8 & West Siberia Lowlands & 55.1 & $\begin{array}{l}\text { Yefremov } \\
\text { and Yefremova (2001) }\end{array}$ \\
\hline & & 70.2 & Sheng et al. (2004) \\
\hline
\end{tabular}

initiation and formation (Yu et al., 2010; Yu, 2011). Yu et al. (2010) estimated a carbon stock of $547 \mathrm{GtC}$ in northern peatlands, with a range of $473-621 \mathrm{GtC}$ based on the standard errors of mean carbon accumulation rates.

The major uncertainties for all approaches discussed above are related to the data coverage gaps and representation of available data. Turunen et al. (2002) indicated that the large differences between various estimates using the peat volume approach (Table 2) were caused by uncertainties in mean peat depth and bulk density values used. Similar uncertainties apply to carbon density values, as they are ultimately based on the values of peat/soil depth, organic matter/carbon concentration, and bulk density used. Also, large errors may be introduced when the data from one peatland region are extrapolated to the entire northern peatlands, as Turunen et al. (2002) did with detailed peatland data from Finland. Underrepresentation of the world's large peatlands (Yu, 2011) and of shallow peats in peatland margins in existing datasets (Kuhry and Turunen, 2006) may be another problem. To increase the representation of mean peat depth and bulk density values, data from other large peatland regions, such as West Siberia (Sheng et al., 2004), continental western Canada (Vitt et al., 2000), and the Mackenzie River Basin (Vitt et al., 2005) should be integrated and synthesized with detailed data available from Finland (Clymo et al., 1998; Turunen et al., 2002). For the time history approach, the major uncertainties are the history of peatland area change over time as well as the representativity of the carbon accumulation records used. For example, likely peatland expansion is highly nonlinear after initiation, as documented at site-scale studies (Korhola, 1994; Korhola et al., 1996; van Bellen et al., 2011; Loisel et al., 2012). Therefore, the assumption of linear peatland expansion used in Yu et al. (2010) might have greatly underestimated the peatland area in their early development history and, as a result, the overall carbon stocks.
In all these studies of carbon stocks in northern peatlands (Table 2), there appears to be a convergence in the total peatland area. Most authors used an area between 3.5 and 4 million $\mathrm{km}^{2}$, so an average of about 3.7 million $\mathrm{km}^{2}$ or a rounded value of 4 million $\mathrm{km}^{2}$, would be a reasonable value to use for Holocene peat carbon stock estimates, especially considering the loss of peatlands through drainage or other disturbances during historical times that have not been considered in some area estimates. This area estimate is similar to the recent estimate of 3.7 million $\mathrm{km}^{2}$ from detailed tabulation of peatland areas in each country of the world (Joosten and Clarke, 2002). These include peatland areas of 0.617 million $\mathrm{km}^{2}$ in Europe, of 1.18 million $\mathrm{km}^{2}$ in Asian part of Russia, and of 1.86 million $\mathrm{km}^{2}$ in North America (1.235 million $\mathrm{km}^{2}$ in Canada, and 0.625 million $\mathrm{km}^{2}$ in the US) (Joosten and Clarke, 2002; their appendix 1). Maltby and Immirzi (1993) estimated the area of northern peatlands at 4 million $\mathrm{km}^{2}$, and Bridgham et al. (2006) used 4 million $\mathrm{km}^{2}$ of global peatland area for their carbon flux calculations. To put the estimates of peatland area in context, estimates for global wetland (including peatlands) area range from 5.26 million $\mathrm{km}^{2}$ (Matthews and Fung, 1987) to 9.167 million $\mathrm{km}^{2}$ (Lehner and Döll, 2004).

For peat carbon stock estimates, it is worth noting that two very different approaches produced surprisingly similar estimates of $455 \mathrm{GtC}$ using the peat volume approach by Gorham (1991) and of $547 \mathrm{GtC}$ using the time history approach by $\mathrm{Yu}$ et al. (2010). Both converge at a rounded figure of $500 \mathrm{GtC}$. Bridgham et al. (2006) estimated that global peatlands contain from 234 to $679 \mathrm{GtC}$ by summing regional data, which includes $178 \mathrm{GtC}$ in North America, with about $150 \mathrm{GtC}$ in Canada (Roulet, 2000; Tarnocai et al., 2005). Botch et al. (1995) estimated a carbon pool of 214 Gt C in peatlands of the Russian Federation. Based on these estimates, peatlands in North America and Russia alone would amount to about $400 \mathrm{GtC}$. Therefore, considering all the uncertainties in estimating these values (see above), it is probably only justifiable and desirable to state the carbon stocks in northern peatlands with one significant figure (Davidson and Janssens, 2006; Yu, 2011). As such, I argue that as a best guess, northern peatlands most likely contain about $500 \pm 100 \mathrm{GtC}$ (or $20 \%$ uncertainty range) on the basis of the review of the literature. A more precise statement and a comprehensive error analysis of carbon stock estimates in northern peatlands are desirable but still out of reach.

\section{Peatland changes over time}

Knowledge about historical trajectories of peatland carbon sequestration is needed to evaluate peatlands contribution to the global carbon cycle during the Holocene. The most widely available datasets are basal peat ages that have been used as a proxy of peatland initiation histories. MacDonald et al. (2006) provided the first comprehensive compilation 
of basal ages from northern peatlands (Fig. 1a), showing peak peatland initiation in the early Holocene, and Yu et al. (2010) presented the similar first datasets for tropical peatlands and southern (mostly Patagonian) peatlands. Several regional compilations of basal peat ages also have been published, including for southern Finland (Korhola, 1995), Western Canada (Halsey et al., 1998; Campbell et al., 2000), West Siberia (Smith et al., 2004), North America (Gorham et al., 2007), and Alaska (Jones and Yu, 2011). The basal ages in MacDonald et al. (2006) have been used to derive a first approximation of peatland area changes over time and is shown in Fig. 1b (Yu et al., 2010). The results show that the area of northern peatlands increased monotonically, but with reduced rate over time during the Holocene (Fig. 1b).

Another aspect of peatland dynamics is carbon accumulation intensity, that is, accumulation rates per unit peatland area. One way to do that is to calculate average $\mathrm{C}$ accumulation rate for a peat profile using a single basal age and total $\mathrm{C}$ amount of the profile. The accumulation rates calculated this way are termed long-term apparent rates of carbon accumulation (LORCA) by Tolonen and Turunen (1996). Tolonen and Turunen (1996) compiled a large dataset of basal ages and total amount of carbon from each of 1028 peatland columns in Finland and found a monotonic increasing trend in apparent carbon accumulation rates during the Holocene, from $\sim 15 \mathrm{~g} \mathrm{C} \mathrm{m}^{-2} \mathrm{yr}^{-1}$ in the early Holocene to $\sim 45 \mathrm{~g} \mathrm{C} \mathrm{m}^{-2} \mathrm{yr}^{-1}$ in the late Holocene. They also found that bogs overall have higher accumulation rates than fens, and there are larger data scatter and variability during the late Holocene than in the early Holocene. Tolonen and Turunen (1996) also plotted and compared similar data from 113 boreal and subarctic peatlands in Western Canada, mostly from Zoltai (1991), and found higher accumulation rates in the recent millennia, with the lowest rates around $4000 \mathrm{yr}$ ago, especially from subarctic peatland sites. In both regions, the recent high accumulation rates were caused by autogenic process due to limited decomposition of recent peat (Clymo, 1984; Belyea and Baird, 2006). However, the depressed carbon accumulation around $4000 \mathrm{yr}$ ago might be caused by the initiation (aggradation) of permafrost during neoglacial climate cooling in this region (Zoltai, 1993). LORCA as calculated using a single basal ages provide unreliable estimates for carbon accumulation, owing to influences of fires, erosion or other disturbance (e.g., Tarnocai et al., 2012). I also argue that the fundamental problem inherent in LORCA data is their inability to identify and locate the time intervals when these disturbances and the reduced carbon accumulation occurred in the past. Some later studies expanded the initial definition of LORCA, unknowingly in some cases, by also including accumulation rates calculated from multiple age determinations along peat profiles, which is discussed below. It has become confusing as both types of accumulation data have different meaning and limitations. So proliferation of these terms and acronyms may not help the understanding and communication of long-term carbon dynamics in peat- lands. However, it may be possible to make more meaningful use of these large and valuable basal age datasets, if a new approach and methodology can be developed in analyzing the data. For example, if we assume that all the basal ages for a region or for the entire northern peatlands were from a Super Peatland (see $\mathrm{Yu}, 2011$ ), then we might be able to derive $\mathrm{C}$ accumulation history by binning these basal ages and deriving $\mathrm{C}$ accumulation rates for individual bins. Of course, this possible approach would require $\mathrm{C}$ measurements (bulk density, and $\mathrm{C}$ content) from these peat profiles with basal ages; however, likely most of these profiles lack such data.

An alternative way to derive carbon accumulation rates is based on peat profiles with multiple age determinations and carbon amount measurements. Using this approach we avoid the problems associated with unidentified disturbancerelated peat removal or slowdown and subsequent underestimate of overall average peat accumulation rates, as we briefly discussed in Yu et al. (2012a). We recently compiled data from a total of 33 peatland sites with multiple ages per site and detailed carbon measurements across the circum-Arctic region (see Fig. 2 for site locations in climate space). We used the dataset to derive a synthesis history of average carbon accumulation rates for northern peatlands, which shows the highest carbon accumulation in the early Holocene (Fig. 1c; Yu et al., 2009). These records would more precisely show any disturbance-related and climate-related loss of carbon at 1000 -yr intervals as reflected in a decrease in carbon accumulation rates.

The product of peatland area and mean carbon accumulation rates for every 1000-yr interval during the Holocene was used to estimate the net carbon pool (NCP) that is currently stored in peatlands (Fig. 1d; Yu, 2011). By taking into account the loss of peat carbon through decomposition after the production and deposition of peat, Yu (2011) used a decay model to back-calculate the amount of carbon lost and provided an estimate of net carbon balance (NCB) for every 1000-yr interval during the Holocene (Fig. 1d). Modeling analysis following different decay rules in Clymo et al. (1998) showed no significant differences or improvement in results (Yu, 2011). In any case, even if different decay rules affect the magnitude of NCB estimates, the pattern of NCB over time will likely remain the same. NCB represents the carbon sequestration by peatlands at different times in the past (including abrupt losses through fire, for example), after taking into account partial subsequent losses through decomposition. So we argue that NCB is the carbon flux term that should be used to discuss contributions of peatlands to the global carbon cycle (Yu, 2011; Yu et al., 2011). Both NCP and NCB represent the same amount of net carbon accumulated in peatlands (so the same area under these two curves in Fig. 1d), but the main difference is their respective histories of carbon sequestration at any time in the past. For example, the observed NCP showed a general increasing trend over the Holocene, while the highest NCB occurred in the early Holocene, as the decomposition loss of old peat 


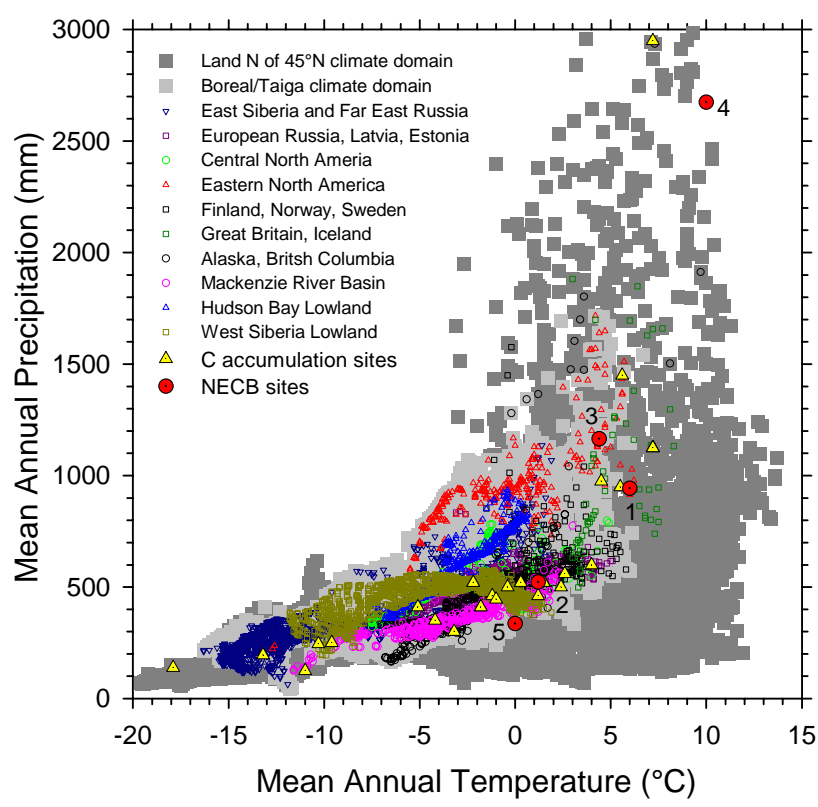

Fig. 2. Distribution of contemporary NECB sites in the climate space of mean annual temperature and precipitation of the northern peatland domain. The locations of NECB (net ecosystem carbon balance) (red circles; $n=5$ ) and Holocene carbon accumulation sites (yellow triangles; $n=33$ ) are shown. NECB site numbers are the same as in Table 3: site 1: Mer Bleue; 2: Degerö; 3: Auchencorth; 4: Glencar; and 5: Stordalen. The 33 carbon accumulation sites were used to derive the synthesis carbon accumulation curve in Fig. 1c (see Yu et al., 2009 for detail and site information). Modified from Yu et al. (2009).

was calculated and added to earlier NCB. Consequently, cumulative histories of NCP and NCB are also different, with cumulative NCB showing sharper increase in carbon stocks earlier in their accumulation histories than cumulative NCP (Fig. 1e). The cumulative NCB results indicate that northern peatlands sequestered close to $400 \mathrm{GtC}$ before $5000 \mathrm{yr}$ ago, about $70 \%$ of the current total of $547 \mathrm{Gt} \mathrm{C}$. The greater $\mathrm{C}$ sequestration in the early Holocene is likely induced by warmer climates in many high-latitude regions dominated by peatlands (Yu et al., 2009, 2010; Jones and Yu, 2010), corresponding to the Holocene thermal maximum (HTM; Kaufman et al., 2004). The subsequent decline in $\mathrm{C}$ sequestration is caused by climate cooling in the late Holocene (Neoglacial cooling) after the HTM and the widespread initiation and formation of permafrost (e.g., Zoltai, 1993).

How does the peatland $\mathrm{C}$ sequestration history from the NCB approach compare with other studies? In their analysis of soil chronosequence data, Harden et al. (1992) indicated that peak peatland expansion occurred $8000-4000 \mathrm{yr}$ ago in glaciated North America. Based on global land ecosystem reconstructions, Adams and Faure (1998) provided an estimate of carbon storage on land since the last glacial maximum. They assumed a constant linear rate of peat carbon stock increase over the Holocene at $46 \mathrm{GtC}$ per $1000 \mathrm{yr}$ for a total peat carbon stock of $466 \mathrm{GtC}$ (Table 2). Halsey et al. (2000) used the abundance of Sphagnum (peat moss) spores as recorded in the North America Pollen Database to map the extent of peatlands in North America. Similarly, Gajewski et al. (2001) scaled up the total carbon stocks of $455 \mathrm{Gt} C$ as estimated by Gorham (1991) throughout the last $21000 \mathrm{yr}$ on the basis of abundance of Sphagnum spores from the Global Pollen Database. Gajewski et al. (2001) found that most peat carbon was accumulated in the late half of the Holocene, with about $350 \mathrm{GtC}$ accumulated in the last $5000 \mathrm{yr}$, about $78 \%$ of $455 \mathrm{GtC}$ total (Fig. 1e). We argue that Sphagnum spores approach likely underestimates the extent of peatlands in the early Holocene, at which time peatlands (mostly rich fens) were often dominated by nonSphagnum plants (Gajewski et al., 2001; MacDonald et al., 2006; Yu, 2011; Yu et al., 2012b). Gorham (1991) also indicated that northern peatlands accumulate their carbon mostly in the late half of the Holocene. These Holocene histories of carbon sequestration were very different from our recent analysis using the time history approach (Yu et al., 2010) and NCB approach (Yu, 2011), as discussed above. At regional scales, Vitt et al. (2000) showed that about half of total carbon stock ( $48 \mathrm{Gt} \mathrm{C}$ ) in peatlands of continental western Canada was observed in the last 3000-2000 yr, but after considering long-term peat decomposition the temporal pattern changed slightly - a similar general pattern as in Gajewski et al. (2001) for northern peatlands. These differences have significant implications for understanding peatlands' role in the global carbon cycle (Yu, 2011; Yu et al., 2011; Ruddiman et al., 2011; Menviel and Joos, 2012). I argue that methods other than the NCB method tend to overestimate late Holocene $\mathrm{C}$ sequestration in peatlands since they do not account for peat decomposition during the period from their deposition until the present.

\section{Carbon fluxes across timescales}

Holocene carbon sequestration histories provide opportunities to assess and understand peatland carbon fluxes over different time scales. "True" instantaneous carbon accumulation rates as derived from NCB (Fig. 1d) and peatland areas over time (Fig. 1b) were plotted on a log scale of ages to emphasize the different time scales (Fig. 3b; Yu et al., 2011). The accumulation rates (NCB) ranged from the highest value of $38 \mathrm{~g} \mathrm{C} \mathrm{m}^{-2} \mathrm{yr}^{-1}$ at $8000-9000 \mathrm{yr}$ ago to the lowest of $5.6 \mathrm{~g} \mathrm{C} \mathrm{m}^{-2} \mathrm{yr}^{-1}$ at 2000-3000 $\mathrm{yr}$ ago. The Holocene average rate is $19 \mathrm{~g} \mathrm{C} \mathrm{m}^{-2} \mathrm{yr}^{-1}$, but the rates were about half of that during the later half of the Holocene. For example, the last millennium had a rate of $10.4 \mathrm{~g} \mathrm{C} \mathrm{m}^{-2} \mathrm{yr}^{-1}$, and the mean rate for the last seven millennia was $11.1 \mathrm{~g} \mathrm{C} \mathrm{m}^{-2} \mathrm{yr}^{-1}$ (Fig. 3b). As the calculations of carbon accumulation rates consider all carbon gains (photosynthetic uptake) and losses (respiratory, leaching and disturbance-related release) from 


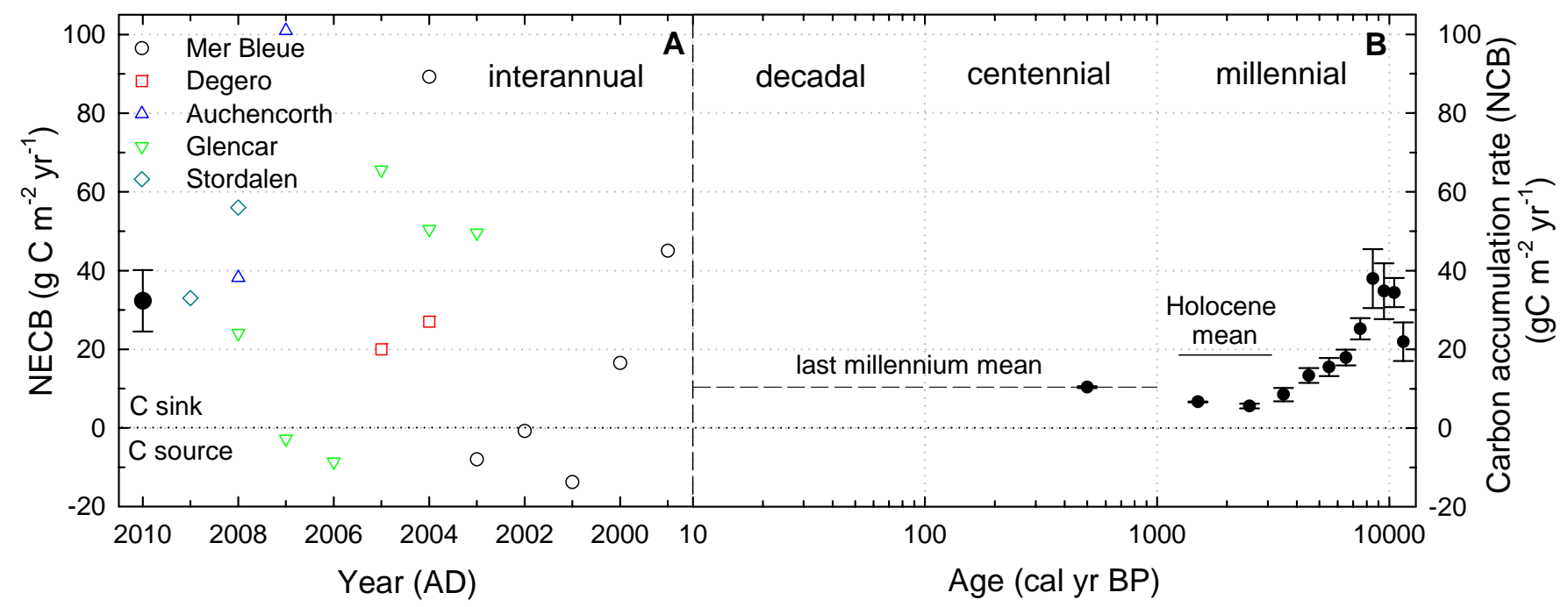

Fig. 3. Net ecosystem carbon balance across time scales in northern peatlands. (A) Net ecosystem carbon balance (NECB) from 5 peatland sites with a total of $18 \mathrm{yr}$ of measurements over the last decade (see Table 4 for details; Mer Bleue: Roulet et al., 2007; Degerö: Nilsson et al., 2008; Auchencorth: Dinsmore et al., 2010; Glencar: Koehler et al., 2011; Stordalen: Olefeldt et al. 2012); (B) peat-core derived net carbon balance (NCB) during the Holocene plotted on log scale to emphasize the different time scales (millennial, centennial and decadal), on the basis of 33 accumulation records (Fig. 1c; Yu et al., 2009) and 1516 basal ages (Fig. 1a; MacDonald et al., 2006).

peatlands during their histories, we argue that these rates are conceptually equivalent to the net ecosystem carbon balance (NECB) as from contemporary carbon flux studies in peatlands and other ecosystem types (Chapin et al., 2006; Olefeldt et al., 2012). However, the time periods used for the NECB measurements or calculations need to be specified when describing NECB as a functioning property of peatland ecosystems, as long-term carbon accumulation rates and contemporary NECB measurements integrate over very different lengths of time. In other words, we do not know how many years would be needed for contemporary NECB to approach a stabilized mean value, or what is the likely variability at centennial, decadal and interannual timescales for each 1000-yr interval of integrated carbon accumulation rates (NCB). Furthermore, other C losses from peatlands, including volatile organic carbon (VOC) (e.g., Holst et al., 2010) and dissolved inorganic carbon (DIC) (e.g., Nilsson et al., 2008; Dinsmore et al., 2010), are implicitly included in historical NCB calculations, but are often not included in NECB estimates. While these $\mathrm{C}$ fluxes are small (for example, $\sim 0.4-9 \mathrm{~g} \mathrm{C} \mathrm{m}^{-2} \mathrm{yr}^{-1}$; Dinsmore et al., 2010; Nilsson et al., 2008), they represent continuous $\mathrm{C}$ losses from peatlands.

How do these long-term Holocene carbon sequestration rates derived from peat-core records compare with contemporary $\mathrm{C}$ flux measurements? To my knowledge, there are five peatland sites that have measurements for most important carbon flux terms over multiple years, including $\mathrm{CO}_{2}$ uptake by photosynthesis and release by ecosystem respiration, $\mathrm{CH}_{4}$ emissions, and dissolved organic carbon (DOC) discharges from peatlands (Table 4; Roulet et al., 2007; Nilsson et al., 2008; Dinsmore et al., 2010; Koehler et al., 2011;
Olefeldt et al., 2012). There are large interannual variations at most of these sites with long records. Also, a large range of NECB was observed among these sites, including the largest carbon sink of $101 \mathrm{~g} \mathrm{C} \mathrm{m}^{-2} \mathrm{yr}^{-1}$ at Auchencorth Moss, Scotland, in 2007 (Dinsmore et al., 2010) and the great carbon source to the atmosphere of $-13.8 \mathrm{~g} \mathrm{C} \mathrm{m}^{-2} \mathrm{yr}^{-1}$ at Mer Bleue, Ontario (Roulet et al., 2007). Most variability at interannual timescale was caused by weather and resultant changes in temperature and peatland hydrology, including water-table influence on species composition of different types of peatlands and on gross ecosystem photosynthesis and ecosystem respiration (Sulman et al., 2010). Obviously, due to the large interannual variability, NECB measurements from any particular year or multiple years may not represent the carbon sequestration capacity for a particular peatland over long timescales. The overall mean of a total of $18 \mathrm{yr}$ of measurements from these five peatland sites is $32.3 \mathrm{~g} \mathrm{C} \mathrm{m}^{-2} \mathrm{yr}^{-1}$ (with a standard error of the mean at $7.8 \mathrm{~g} \mathrm{C} \mathrm{m}^{-2} \mathrm{yr}^{-1}$ ), shown as a solid circle in Fig. 3a. This averaged value is different from the average of site means as shown in Table 4, as different weightings (years vs. sites) were used for both calculations. The carbon accumulation rate as estimated by NECB studies is about three-fold higher than the rates in the last millennium $\left(10.4 \mathrm{~g} \mathrm{C} \mathrm{m}^{-2} \mathrm{yr}^{-1}\right)$ or the mean rate over the last seven millennia (11.1 $\mathrm{g} \mathrm{C} \mathrm{m}^{-2} \mathrm{yr}^{-1}$ ) (Fig. 3b). Also, when comparing the contemporary NECB at individual sites with the carbon accumulation rates at the nearest long-term sites in temperature-precipitation space (Fig. 2), I found that NECB is about 2 to 7 times higher than Holocene average carbon accumulation rates (Yu et al., 2009; their Table 1). However, 
Table 4. Contemporary net ecosystem carbon balance (NECB) from northern peatlands*.

\begin{tabular}{|c|c|c|c|c|c|c|c|c|c|c|c|c|c|}
\hline$\#$ & Site & $\begin{array}{l}\text { Latitude } \\
\left({ }^{\circ} \mathrm{N}\right)\end{array}$ & $\begin{array}{r}\text { Longitude } \\
\left({ }^{\circ} \mathrm{E}\right)\end{array}$ & $\begin{array}{l}\text { Altitude } \\
\text { (ma.s.l.) }\end{array}$ & $\begin{array}{l}\text { MAT } \\
\left({ }^{\circ} \mathrm{C}\right)\end{array}$ & $\begin{array}{l}\text { MAP } \\
(\mathrm{mm})\end{array}$ & $\begin{array}{l}\text { Peatland } \\
\text { type }\end{array}$ & $\begin{array}{l}\text { Measurement } \\
\text { period }\end{array}$ & $\begin{array}{r}\text { NECB } \\
\left(\mathrm{gCm}^{-2} \mathrm{yr}^{-1}\right) \\
\pm 1 \mathrm{SD}\end{array}$ & $\begin{array}{r}\mathrm{NEE} \\
\left(\mathrm{g} \mathrm{C}^{-\mathrm{CO}_{2}}\right. \\
\left.\mathrm{m}^{-2} \mathrm{yr}^{-1}\right)\end{array}$ & $\begin{array}{r}\mathrm{CH}_{4} \\
\left(\mathrm{~g} \mathrm{C}^{-\mathrm{CH}_{4}}\right. \\
\left.\mathrm{m}^{-2} \mathrm{yr}^{-1}\right)\end{array}$ & $\begin{array}{r}\text { DOC } \\
\left(\mathrm{g} \mathrm{C} \mathrm{m}^{-2}\right. \\
\left.\mathrm{yr}^{-1}\right)\end{array}$ & Reference \\
\hline 1 & $\begin{array}{l}\text { Mer Bleue } \\
\text { (Canada) }\end{array}$ & 45.41 & -75.48 & 69 & 6 & 943 & $\begin{array}{l}\text { Ombotrophic } \\
\text { bog }\end{array}$ & $1998-2004$ & $21.5 \pm 39.0$ & $40.2 \pm 40.5$ & $3.7 \pm 0.5$ & $14.9 \pm 3.1$ & $\begin{array}{l}\text { Roulet } \\
\text { et al. (2007) }\end{array}$ \\
\hline 2 & $\begin{array}{l}\text { Degerö } \\
\text { Stormyr } \\
\text { (Sweden) }\end{array}$ & 64.18 & 19.55 & 270 & 1.2 & 523 & $\begin{array}{l}\text { Minerogenic } \\
\text { fen }\end{array}$ & 2004-2005 & $24 \pm 4.9$ & $51.5 \pm 4.9$ & $11.5 \pm 3.5$ & $17.7 \pm 3.7$ & $\begin{array}{l}\text { Nilsson } \\
\text { et al. (2008) }\end{array}$ \\
\hline 3 & $\begin{array}{l}\text { Auchencorth } \\
\text { Moss** } \\
\text { (Scotland) }\end{array}$ & 55.79 & -3.24 & 265 & 4.4 & 1165 & $\begin{array}{l}\text { Ombrotrophic } \\
\text { bog }\end{array}$ & 2007-2008 & $69.5 \pm 44.4$ & $114.7 \pm 30.1$ & $0.32 \pm 0.04$ & $25.4 \pm 9.6$ & $\begin{array}{l}\text { Dinsmore } \\
\text { et al. (2010) }\end{array}$ \\
\hline 4 & $\begin{array}{l}\text { Glencar } \\
\text { (Ireland) }\end{array}$ & 51.92 & -9.92 & 150 & 10 & 2674 & $\begin{array}{l}\text { Blanket } \\
\text { bog }\end{array}$ & $2003-2008$ & $29.7 \pm 30.6$ & $47.8 \pm 30$ & $4.1 \pm 0.5$ & $14.0 \pm 1.6$ & $\begin{array}{l}\text { Koehler } \\
\text { et al. }(2011)\end{array}$ \\
\hline 5 & $\begin{array}{l}\text { Stordalen } \\
\text { (Sweden) }\end{array}$ & 68.37 & 19.05 & 351 & 0 & 336 & $\begin{array}{l}\text { Permafrost } \\
\text { palsa mire }\end{array}$ & 2008-2009 & $44.5 \pm 16.3$ & $50 \pm 17.0$ & 2.0 & $3.2 \pm 0.6$ & $\begin{array}{l}\text { Olefeldt } \\
\text { et al. (2012) }\end{array}$ \\
\hline \multicolumn{9}{|c|}{ Average of 5 sites $\left(\mathrm{g} \mathrm{C} \mathrm{m}^{-2} \mathrm{yr}^{-1}\right)(\%$ of NEE) } & $37.8(62 \%)$ & 60.8 & $4.3(7.1 \%)$ & $15.0(24.7 \%)$ & \\
\hline
\end{tabular}

* NECB: net ecosystem carbon balance; NEE: net ecosystem exchange; DOC: dissolved organic carbon; MAT: mean annual temperature; and MAP: mean annual precipitation.

** Auchencorth Moss has flux measurements from other processes, including stream evasion of $\mathrm{CO}_{2}$ and $\mathrm{CH}_{4}$, so the figures listed do not balance, that is,

$\mathrm{NEE}>\mathrm{NECB}+\mathrm{CH}_{4}+\mathrm{DOC}$.

it is interesting to note that a first direct comparative study at Mer Bleue showed no statistical difference between contemporary NECB and carbon accumulation rates estimated for the last $3000 \mathrm{yr}$ from peat-core analysis (Roulet et al., 2007).

If derived Holocene NCB represents true carbon accumulation robustly and accurately, and if the measured contemporary NECB are representative of these ecosystems, then what could have contributed to the much higher NECB at these flux sites over the recent decade? We speculated that the environmental conditions at the present may no longer be "natural" owing to recent anthropogenic global changes, including climate warming, elevated $\mathrm{CO}_{2}$ concentration and subsequent $\mathrm{CO}_{2}$ fertilization effect, and increased nitrogen deposition (Yu et al., 2011). The updated mean value of $32.3 \mathrm{~g} \mathrm{C} \mathrm{m}^{-2} \mathrm{yr}^{-1}$ from 5 sites presented here is higher than the mean of $25 \mathrm{~g} \mathrm{C} \mathrm{m}^{-2} \mathrm{yr}^{-1}$ from three sites (Yu et al., 2011), suggesting again the high interannual and betweensite variability of contemporary NECB measurements. Alternatively, these contemporary study sites are not representative of most peatlands in these regions, as researchers tend to select more productive and less-disturbed sites for eddy covariance tower and other flux measurements. Fires and possibly flooding have been frequent disturbances in peatlands during the Holocene that often cause large carbon loss from ecosystems and reduced net carbon accumulation rates (e.g., Bhiry et al., 2007; St. Louis et al., 2000; Turetsky et al., 2011a, b), and these carbon losses were implicitly accounted for in our Holocene NCB calculations. For example, recent studies in boreal peatlands show that several hundred years of $\mathrm{C}$ accumulation can be lost in peatland fires (Turetsky et al., 2011b). However, these disturbances were likely not encountered during the period of carbon flux measurements at these flux study sites. Furthermore, in temperatureprecipitation climate space, all these sites are located near the warm fringe of the boreal peatland domain, although spanning essentially the entire precipitation range (Fig. 2). While all these NECB sites represent peatlands under the warmest climates with similar precipitation, while the sites used for peat-core derived estimates of Holocene NCB were more widely distributed in the northern peatland climate domain (Fig. 2). If the NECB is indeed higher at the warm fringe than under a cold climate, then this observation suggests that temperature is a dominant control on peatland carbon balance at this spatial scale. This suggestion appears to be supported by peatland $\mathrm{CO}_{2}$ flux studies. In a synthesis of eddy covariance flux studies from 12 wetland sites (peatlands and wet tundra) from temperate to Arctic climates, Lund et al. (2010) found that the length of growing seasons is the most important variable explaining the spatial variation in summertime gross primary production and ecosystem respiration, both together determining the net ecosystem exchange (that is, $\mathrm{CO}_{2}$ flux component of NECB). Also, Lund et al. (2010) concluded from their synthesis results that gross primary production would increase more with a prolonged growing season as compared with ecosystem respiration. This suggests that a warm climate would stimulate more carbon uptake. Therefore, if there is no major difference in $\mathrm{CH}_{4}$ and DOC fluxes among these sites, it is possible that these high contemporary flux sites only capture NECB from the most productive peatlands under warm climates, which do not necessarily represent other northern peatlands.

In reality, there are major differences in $\mathrm{CH}_{4}$ and DOC fluxes in different peatlands (Table 4). Net $\mathrm{C}$ sequestration (NECB) on average accounts for $62 \%$ (ranging from 47 to $89 \%$ ) of total photosynthetic $\mathrm{C}$ input (NEE), while $\mathrm{C}$ losses as $\mathrm{CH}_{4}$ account for $7 \%$ (from $<1$ to $22 \%$ ) and DOC for $25 \%$ (from 6 to $37 \%$ ). It is not surprising that wet fens (e.g., Degerö Stormyr) have high C losses from $\mathrm{CH}_{4}$ emissions, while dry bogs and permafrost peatlands have the lowest $\mathrm{CH}_{4}$ emissions (e.g., Auchencorth Moss, and Stordalen). Also, permafrost peatlands have lower DOC export than non-permafrost peatlands (Olefeldt et al., 2012). 
If these relative contributions of different $\mathrm{C}$ fluxes to overall $\mathrm{C}$ balance are representative for different types of peatlands, then we can gather additional net $\mathrm{C}$ balance information from partial $\mathrm{C}$ flux data at more sites. This will compensate the lack of NECB sites for comparison with historical data, but we should be cautious as we do not know if the data from these few sites are representative. Among the sites with full year measurements reviewed by Lund et al. (2010) using La Thuile Fluxnet dataset, NEE values range from a low of $22 \mathrm{~g} \mathrm{C} \mathrm{m}^{-2} \mathrm{yr}^{-1}$ in a subarctic fen in northern Finland (Aurela et al., 2004) to a high of $144 \mathrm{~g} \mathrm{C} \mathrm{m}^{-2} \mathrm{yr}^{-1}$ in a rich fen in boreal western Canada (Syed et al., 2006). Recently Frolking et al. (2011) provided a review of NEE and $\mathrm{CH}_{4}$ fluxes from global undisturbed and disturbed peatlands in the literature and found that northern (non-tropical) peatlands have a median value of $40 \mathrm{~g} \mathrm{C} \mathrm{m}^{-2} \mathrm{yr}^{-1}$ (ranging from 20 to $100 \mathrm{~g} \mathrm{C} \mathrm{m}^{-2} \mathrm{yr}^{-1}$ ) in NEE and of $7.5 \mathrm{~g} \mathrm{C}_{-} \mathrm{CH}_{4} \mathrm{~m}^{-2} \mathrm{yr}^{-1}$ (ranging from 1 to $52 \mathrm{~g} \mathrm{C} \mathrm{m}^{-2} \mathrm{yr}^{-1}$ ) in $\mathrm{CH}_{4}$ emissions. The NEE and $\mathrm{CH}_{4}$ fluxes from NECB sites (Table 4) are close to the center values of these data ranges. Even at sites with only $\mathrm{C}$ flux data during growing seasons using chamber technique, some studies show that peatlands have a delicate $\mathrm{C}$ balance, switching between $\mathrm{C}$ sinks and sources, depending on microtopography and weather/climate (e.g., Alm et al., 1999; Schneider et al., 2012). Also, Fraser et al. (2001) reviewed DOC export from wetlands and found that it ranges from 1 to $48 \mathrm{~g} \mathrm{C} \mathrm{m}^{-2} \mathrm{yr}^{-1}$ from 13 wetland sites, with a mean of $\sim 16 \mathrm{~g} \mathrm{C} \mathrm{m}^{-2} \mathrm{yr}^{-1}$. The DOC values from 5 NECB sites are within this range, with a similar site mean (Table 4).

Spatial scales have been considered as an important factor affecting carbon dynamics in peatlands (Waddington and Roulet, 2000; Belyea and Baird, 2006; Limpens et al., 2008; Baird et al., 2009). However, less attention has been paid to the discussion of temporal scales in the literature. Peatland carbon dynamics may have been controlled by different factors at different temporal and spatial scales. For example, both hydrology and temperature may play major roles in determining the carbon balance at interannual scales at individual sites (Fig. 3a), but some data show that summer temperature might have played a major role in carbon accumulation at millennial scales in the early Holocene over the entire northern peatlands (Yu et al., 2009, 2010) and at the regional scale in Alaska (Jones and Yu, 2010). Also, temperature and precipitation may have different impacts on different components of the carbon balance $\left(\mathrm{CO}_{2}, \mathrm{CH}_{4}\right.$ and DOC) (see above discussion; Lund et al., 2010). Therefore, it is conceivable that different factors may control carbon dynamics and balance at decadal and centennial time scales, the most relevant time scales for climate impact and feedback assessments ( $\mathrm{Yu}$ et al., 2011). However, at the present there are major data and knowledge gaps at this intermediate timescale (Fig. 3).

\section{Concluding remarks}

The following outstanding issues and relevant future research directions are discussed for improving peatland carbon stock estimates and for understanding peatland carbon dynamics.

\subsection{Filling data gaps and increasing data representation}

We have very limited data and information from several large peatland regions in the world, including the Hudson Bay Lowlands (see some paleo studies in Glaser et al., 2004, and general overview of these peatlands in Riley, 2011), East Siberia and the Far East of Russia (Yu et al., 2009). Filling these data gaps is essential for robust estimates of peatland carbon stocks and Holocene carbon dynamics. Also, it would be preferable and ideal to generate separate carbon stock estimates for different regions, as done for continental western Canada (Vitt et al., 2000), Finland (Turunen et al., 2002), West Siberia (Sheng et al., 2004), and the Mackenzie River Basin (Vitt et al., 2005; Beilman et al., 2008), before we sum all these together to derive estimates for the entire northern peatlands. This means that we need to develop region-specific values of mean peat depth and bulk density values using the peat volume approach (or carbon density approach). Similarly, regional patterns of peat carbon accumulation could be developed if more accumulation records were available from different regions. If so, eventually not only a more representative database will be developed for the entire northern peatlands, but also we will have the information to discuss regional differences in peatland carbon sequestration and their controls by regional climate. One possible way to expand the carbon accumulation records is to use the still underutilized basal peat age database $(>2500$ compiled dates available; MacDonald et al., 2006; Gorham et al., 2007; Kohorla et al., 2010) for calculating LORCA as described in Tolonen and Turunen (1996). However, a new approach needs to be developed to decompose the observed LORCA data into net carbon balance (NCB) or its equivalent, as described earlier. Also, it would be useful to compare results of carbon stock estimates of the same region using different (e.g., peat volume vs. time history) approaches.

\subsection{Establishing empirical relationship and process understanding}

Before we reach our goals of sampling all major peatland complexes, we inevitably need to extrapolate knowledge learned from subsets of peatland regions to the entire northern peatlands. Understanding peatland processes and establishing empirical relationships between important peatland properties (area, depth, and ages) in well-studied regions are essential to make immediate progress in generating more robust carbon stock estimates. For example, Zoltai (1991) and Vitt et al. (2000) developed relationships between peat 
ages and depth (cumulative mass) from their large regional datasets or individual sites from west-central Canada. Thus, it would be highly valuable to establish relationships of the essential parameters of depth, ages and bulk density for different types of peatlands in regions that have detailed information (Finland: Clymo et al., 1998; Turunen et al., 2002; continental western Canada and the Mackenzie River Basin: Vitt et al., 2000, 2005; West Siberia: Sheng et al., 2004). Then, these relationships can be used to estimate essential parameters and carbon stocks in other remote or understudied regions. A promising approach would be to stratify other peat carbon properties (such as bulk density, carbon density) by peatland types and stratigraphic depths as suggested by Beilman et al. (2008). Riley (2011) also emphasized the importance of establishing the relationship between peatland types and peat depth in calculating peat volume and carbon, as in remote parts of the Hudson Bay Lowlands. Also, the established relationships may contribute to the development of new approaches for using basal ages and the derived LORCA for modeling net carbon balance.

\subsection{Focusing on peatland lateral expansion data and process}

Peatland lateral expansion is an important process that is likely controlled by local topography and regional climate. Peatland expansion dynamics during the Holocene directly affects the estimates of change in peatland area over time. There are limited data available at individual sites, as the data collections and analysis are often expensive and labor intensive (see Korhola, 1994; Bauer et al., 2003; van Bellen et al., 2011; Loisel et al., 2012). As a result, peatland expansion processes are not well understood. The novel method of analyzing the multidate datasets as presented in Korhola et al. (2010), would be needed to derive a robust peatland expansion history during the Holocene. Also, more studies at peatland site scale are needed, especially using the combination of ground penetration radar (GPR) for large-scale survey and peat-core analysis for detailed depth and age determinations. This approach has been successfully used in some recent studies (van Bellen et al., 2011; Loisel et al., 2012). In the future, combining GPR, LIDAR and other remote sensing tools with peat-core analysis will allow us to generate not only surface morphology information but also subsurface stratigraphy to understand peatland expansion processes on landscape at the present and in the past. Also, a general model of peatland lateral expansion that incorporates climate (e.g., precipitation, or recharge rate) and topography (e.g., slope), potentially modified and integrated from existing models (e.g., Ingram, 1982; Couwenberg, 2005; Morris et al., 2011), would help derive necessary parameters for estimating peatland expansion rates during the Holocene.

\subsection{Understanding carbon dynamics across timescales}

There are major data and knowledge gaps at the timesscales of decades and centuries (Fig. 3), which prevent understanding peatland carbon dynamics at this intermediate, but most relevant, timescale. ${ }^{210} \mathrm{~Pb}$ and post-bomb AMS ${ }^{14} \mathrm{C}$ dating and carbon analysis of recent peat cores are needed to fill this important data gap (e.g., Wieder, 2001; Turetsky et al., 2004; Malmer and Wallén, 2004). Datasets used in a recent data synthesis of the last millennium peat carbon dynamics (Charman et al., 2012) can be further explored for deriving net carbon balance at $100-\mathrm{yr}$ intervals for the last 1000 yr. Also, as pointed out by Roulet et al. (2007), we "need more replications across a diverse set of ecoclimatic regions and other peatland types" for contemporary NECB measurements, and I argue that measurements from sites in colder boreal and subarctic climates would fill an important data and knowledge gap (Fig. 2). In addition to largescale synthesis effort, further analyzing contemporary flux and paleo data from the same site (e.g., Roulet et al., 2007) by decomposing peat-core data to NECB equivalent at site scale (Yu, 2011) may provide insights into carbon dynamics across different timescales. Robust comparisons between long-term and contemporary carbon balance would also require a systematic error analysis, but this goal is still elusive due to underrepresentation of both types of data. Meanwhile, a data-model assimilation procedure may be useful to decompose peat-core data into short-term NECB or to integrate annual NECB measurements into long-term averages of peatland carbon balance. Also, process modeling (e.g., Frolking et al., 2010) will be essential in understanding the roles of different environmental parameters (temperature, precipitation, and hydrology) in determining carbon accumulation at various (interannual, decadal, centennial, and millennial) timescales.

Acknowledgements. I thank Nigel Roulet for his insightful and constructive criticism and comments, Dave Beilman and Julie Loisel for their helpful suggestions, and two journal referees, especially David Olefeldt, for their constructive, thoughtful and detailed comments on the manuscript. Considering these feedbacks greatly improved the manuscript. I acknowledge that the idea to review peatland carbon stocks was stimulated through a conversation with Pep Canadell in July 2011 and that the necessary literature research and writing were initiated in January 2012. I dedicate this paper to Robert E. Moeller (1949-2011). Some of the ideas presented in this paper were generated while undertaking peatland research projects funded by the US NSF grants (ATM-0628455; EAR-0819717; DEB-0919385; and ARC-1107981).

Edited by: P. Stoy 


\section{References}

Adams, J. M. and Faure, H.: A new estimate of changing carbon storage on land since the last glacial maximum, based on global land ecosystem reconstruction, Global Planet. Change, 16/17, 324, 1998.

Alm, J., Schulman, L., Walden, J., Nykänen, H., Martikainen, P. J., and Silvola, J.: Carbon balance of a boreal bog during a year with an exceptionally dry summer, Ecology, 80, 161-174, 1999.

Armentano, T. V. and Menges, E. S.: Patterns of change in the carbon balance of organic soil-wetlands of the temperate zone, J. Ecol., 74, 755-774, 1986.

Aurela, M., Laurila, T., and Tuovinen, J. P.: The timing of snow melt controls the annual $\mathrm{CO}_{2}$ balance in a subarctic fen, Geophys. Res. Lett., 31, L16119, doi:10.1029/2004GL020315, 2004.

Baird, A. J., Belyea, L. R., and Morris, P. J.: Upscaling of peatlandatmosphere fluxes of methane: Small-scale heterogeneity in process rates and the pitfalls of "bucket-and-slab" models, in: Carbon Cycling in Northern Peatlands, AGU Geophysical Monograph vol. 184, edited by: Baird, A., Belyea, L., Comas, X., Reeve, A., and Slater, L., 37-53. doi:10.1029/2008GM000826, 2009.

Bauer, I. E., Gignac, L. D., and Vitt, D. H.: Development of a peatland complex in boreal western Canada: Lateral site expansion and local variability in vegetation succession and long-term peat accumulation, Can. J. Bot., 81, 833-847, 2003.

Beilman, D. W., Vitt, D. H., Bhatti, J. S., and Forest, S.: Peat carbon stocks in the southern Mackenzie River Basin: uncertainties revealed in a high-resolution case study, Glob. Change Biol., 14, 1221-1232, doi:10.1111/j.1365-2486.2008.01565.x, 2008.

Belyea, L. R. and Baird, A. J.: Beyond the limits to peat bog growth: cross-scale feedback in peatland development, Ecol. Monogr., 76, 299-322, 2006.

Bhiry, N., Payette, S., and Robert, E.: Peatland development at the arctic tree line (Quebec, Canada) influenced by flooding and permafrost, Quaternary Res., 67, 426-437, 2007.

Botch, M. S., Kobak, K. I., Vinson, T. S., and Kolchugina, T. P.: Carbon pools and accumulation in peatlands of the Former Soviet Union, Global Biogeochem. Cy., 9, 37-46, 1995.

Bridgham, S. D., Megonigal, J. P., Keller, J. K., Bliss, N. B., and Trettin, C.: The carbon balance of North American wetlands, Wetlands, 26, 889-916, 2006.

Brovkin, V., Bendtsen, J., Claussen, M., Ganopolski, A., Kubatzki, C., Petoukhov, V., and Andreev, A.: Carbon cycle, vegetation, and climate dynamics in the Holocene: Experiments with the CLIMBER-2 model, Global Biogeochem. Cy., 16, 1139, doi:10.1029/2001GB001662, 2002.

Campbell, I. D., Campbell, C., Yu, Z. C., Vitt, D. H., and Apps, M. J.: Millennial-scale rhythms in peatlands in the western interior of Canada and in the global carbon cycle, Quaternary Res., 54, 155-158, 2000.

Chapin, F. S., Woodwell, G. M., Randerson, J. T., Rastetter, E. B., Lovett, G. M., Baldocchi, D. D., Clark, D. A., Harmon, M. E., Schimel, D. S., Valentini, R., Wirth, C., Aber, J. D., Cole, J. J., Goulden, M. L., Harden, J. W., Heimann, M., Howarth, R. W., Matson, P. A., McGuire, A. D., Melillo, J. M., Mooney, H. A., Neff, J. C., Houghton, R. A., Pace, M. L., Ryan, M. G., Running, S. W., Sala, O. E., Schlesinger, W. H., and Schulze, E. D.: Reconciling carbon-cycle concepts, terminology, and methods, Ecosystems, 9, 1041-1050, 2006.
Charman, D. J., Beilman, D. W., Blaauw, M., Booth, R. K., Brewer, S., Chambers, F. M., Christen, J. A., Gallego-Sala, A., Harrison, S. P., Hughes, P. D. M., Jackson, S. T., Korhola, A., Mauquoy, D., Mitchell, F. J. G., Prentice, I. C., van der Linden, M., De Vleeschouwer, F., Yu, Z. C., Alm, J., Bauer, I. E., Corish, Y. M. C., Garneau, M., Hohl, V., Huang, Y., Karofeld, E., Le Roux, G., Loisel, J., Moschen, R., Nichols, J. E., Nieminen, T. M., MacDonald, G. M., Phadtare, N. R., Rausch, N., Sillasoo, Ü., Swindles, G. T., Tuittila, E.-S., Ukonmaanaho, L., Väliranta, M., van Bellen, S., van Geel, B., Vitt, D. H., and Zhao, Y.: Climate-related changes in peatland carbon accumulation during the last millennium, Biogeosciences Discuss., 9, 14327-14364, doi:10.5194/bgd-9-14327-2012, 2012.

Clymo, R. S.: The limits to peat bog growth, Philos. T. R. Soc. Lon. B, 303, 605-654, 1984.

Clymo, R. S., Turunen, J., and Tolonen, K.: Carbon accumulation in peatland, Oikos, 81, 368-388, 1998.

Couwenberg, J.: A simulation model of mire patterning - revisited, Ecography, 28, 653-661, 2005.

Davidson, E. A. and Janssens, I. A.: Temperature sensitivity of soil carbon decomposition and feedbacks to climate change, Nature, 440, 165-173, 2006.

Dinsmore, K. J., Billett, F. M., Skiba, U. M., Rees, R. M., Drewer, J., and Helfter, C.: Role of the aquatic pathway in the carbon and greenhouse gas budgets of a peatland catchment, Glob. Change Biol., 16, 2750-2762, doi:10.1111/j.1365-2486.2009.02119.x, 2010.

Fraser, C. J. D., Roulet, N. T., and Moore, T. R.: Hydrology and dissolved organic carbon biogeochemistry in an ombrotrophic bog, Hydrol. Process., 15, 3151-3166, 2001.

Frolking, S., Roulet, N. T., Tuittila, E., Bubier, J. L., Quillet, A., Talbot, J., and Richard, P. J. H.: A new model of Holocene peatland net primary production, decomposition, water balance, and peat accumulation, Earth Syst. Dynam., 1, 1-21, doi:10.5194/esd-11-2010, 2010.

Frolking, S., Talbot, J., Jones, M. C., Treat, C. C., Kauffman, J. B., Tuittila, E.-S., and Roulet, N.: Peatlands in the Earth's 21st century coupled climate-carbon system, Environ. Rev., 19, 371396, 2011.

Gajewski, K., Viau, A., Sawada, M., Atkinson, D., and Wilson, S.: Sphagnum peatland distribution in North America and Eurasia during the past 21,000 years, Global Biogeochem. Cy., 15, $297-$ 310, 2001.

Glaser, P. H., Hansen, B. C. S., Siegel, D. I., Reeve, A. S., and Morin, P. J.: Rates, pathways and drivers for peatland development in the Hudson Bay Lowlands, northern Ontario, Canada, J. Ecol., 92, 1036-1053, 2004.

Gorham, E.: Biotic impoverishment in northern peatlands, in: The earth in transition: patterns and processes of biotic impoverishment, edited by: Woodwell, G. M., Cambridge University, New York, NY, 65-98, 1990.

Gorham, E.: Northern peatlands: Role in the carbon cycle and probable responses to climatic warming, Ecol. Appl., 1, 182-195, 1991.

Gorham, E., Lehman, C., Dyke, A., Janssens, J., and Dyke, L.: Temporal and spatial aspects of peatland initiation following deglaciation in North America, Quaternary Sci. Rev., 26, 300311, 2007. 
GSDTG (Global Soil Data Task Group): Global Gridded Surfaces of Selected Soil Characteristics (IGBP-DIS), available at: http: //www.daac.ornl.gov, doi:10.3334/ORNLDAAC/569, 2000.

Halsey, L. A., Vitt, D. H., and Bauer, I. E.: Peatland initiation during the Holocene in continental western Canada, Climatic Change, 40, 315-342, 1998.

Halsey, L., Vitt, D. H., and Gignac, L. D.: Sphagnum-dominated peatlands in North America since the last glacial maximum: Their occurrence and extent, Bryologist, 103, 334-352, 2000.

Harden, J. W., Sundquist, E. T., Stallard, R. F., and Mark, R. K.: Dynamics of soil carbon during deglaciation of the Laurentide ice sheet, Science, 258, 1921-1924, 1992.

Holst, T., Arneth, A., Hayward, S., Ekberg, A., Mastepanov, M., Jackowicz-Korczynski, M., Friborg, T., Crill, P. M., and Bäckstrand, K.: BVOC ecosystem flux measurements at a high latitude wetland site, Atmos. Chem. Phys., 10, 1617-1634, doi:10.5194/acp-10-1617-2010, 2010.

Ingram, H. A. P.: Size and shape in raised mire ecosystems: a geophysical model, Nature, 297, 300-303, 1982.

Jones, M. C. and Yu, Z. C.: Rapid deglacial and early Holocene expansion of peatlands in Alaska, P. Natl. Acad. Sci. USA, 107, 7347-7352, 2010.

Joosten, H. and Clarke, D.: Wise use of mires and peatlands, International Mire Conservation Group and International Peat Society, Saarijärvi, Finland, 2002.

Kaufman, D. S., Ager, T. A., Anderson, N. J., Anderson, P. M., Andrews, J. T., Bartlein, P. J., Brubaker, L. B., Coats, L. L., Cwynar, L. C., Duvall, M. L., Dyke, A. S., Edwards, M. E., Eisner, W. R., Gajewski, K., Geirsdottir, A., Hu, F. S., Jennings, A. E., Kaplan, M. R., Kerwin, M. W., Lozhkin, A. V., MacDonald, G. M., Miller, G. H., Mock, C. J., Oswald, W. W., Otto-Bliesner, B. L., Porinchu, D. F., Ruhland, K., Smol, J. P., Steig, E. J., and Wolfe, B. B.: Holocene thermal maximum in the western Arctic (0-180 W), Quaternary Sci. Rev., 23, 529-560, 2004.

Kleinen, T., Brovkin, V., von Bloh, W., Archer, D., and Munhoven, G.: Holocene carbon cycle dynamics, Geophys. Res. Lett., 37, L02705, doi:10.1029/2009GL041391, 2010.

Koehler, A.-K., Sottocornola, M., and Kiely, G.: How strong is the current carbon sequestration of an Atlantic blanket bog?, Glob. Change Biol., 17, 309-319, doi:10.1111/j.13652486.2010.02180.x, 2011.

Korhola, A.: Radiocarbon evidence for rates of lateral expansion in raised mires in southern Finland, Quaternary Res., 42, 299-307, 1994.

Korhola, A.: Holocene climatic variations in southern Finland reconstructed from peat-initiation data, Holocene, 5, 43-58, 1995.

Korhola, A., Alm, J., Tolonen, K., Turunen, J., and Junger, H.: Three-dimensional reconstruction of carbon accumulation and $\mathrm{CH}_{4}$ emission during nine millennia in a raised mire, J. Quaternary Sci., 11, 161-165, 1996.

Korhola, A., Ruppel, M., Seppä, H., Väliranta, M., Virtanen, T., and Weckström, J.: The importance of northern peatland expansion to the late-Holocene rise of atmospheric methane, Quaternary Sci. Rev., 29, 611-617, 2010.

Kuhry, P. and Turunen, J.: The postglacial development of boreal and subarctic peatlands, in: Boreal Peatland Ecosystems, edited by: Wieder, R. K. and Vitt, D. H., Ecological Studies Series, vol. 188, Springer, New York, 25-46, 2006.
Lappalainen, E.: General review on world peatlands and peat resources, in: Global peat resources, International Peat Society, Jyska, Finland, 53-56, 1996.

Lehner, B. and Döll, P.: Development and validation of a global database of lakes, reservoirs and wetlands, J. Hydrol., 296, 1-22, 2004.

Limpens, J., Berendse, F., Blodau, C., Canadell, J. G., Freeman, C., Holden, J., Roulet, N., Rydin, H., and Schaepman-Strub, G.: Peatlands and the carbon cycle: from local processes to global implications - a synthesis, Biogeosciences, 5, 1475-1491, doi:10.5194/bg-5-1475-2008, 2008.

Loisel, J., Yu, Z. C., Parkesian, A., Nolan, J. T., and Slater, L. D.: Quantifying landscape morphology influence on peatland lateral expansion using ground penetrating radar (GPR) and peat core analysis, in review, 2012.

Lund, M., Lafleur, P. M., Roulet, N. T., Lindroth, A., Christensen, T. R., Aurela, M., Chojnicki, B. H., Flanagan, L. B., Humphreys, E. R., Laurila, T., Oechel, W. C., Olejnik, J., Rinne, J., Schubert, P., and Nilsson, M. B.: Variability in exchange of $\mathrm{CO}_{2}$ across 12 northern peatland and tundra sites, Glob. Change Biol., 16, 2436-2448, doi:10.1111/j.1365-2486.2009.02104.x, 2010.

MacDonald, G. M., Beilman, D. W., Kremenetski, K. V., Sheng, Y., Smith, L. C., and Valichko, A. A.: Rapid early development of circumarctic peatlands and atmospheric $\mathrm{CH}_{4}$ and $\mathrm{CO}_{2}$ variations, Science, 314, 285-288, 2006.

Malmer, N. and Wallén, B.: Input rates, decay losses and accumulation rates of carbon in bogs during the last millennium: internal processes and environmental changes, Holocene, 14, 111-117, 2004.

Mäkilä, M.: Calculation of the energy content of mires on the basis of peat properties, Geol. S. Finland, Report of Investigation, 121, 1-73, 1994.

Maltby, E. and Immirzi, P.: Carbon dynamics in peatlands and other wetland soils, regional and global perspectives, Chemosphere, 27, 999-1023, 1993.

Matthews, E. and Fung, I.: Methane emission from natural wetlands: Global distribution, area, and environmental characteristics of sources, Global Biogeochem. Cy., 1, 61-86, doi:10.1029/GB001i001p00061, 1987.

Menviel, L. and Joos, F.: Toward explaining the Holocene carbon dioxide and carbon isotope records: Results from transient ocean carbon cycle-climate simulations, Paleoceanography, 27, PA1207, doi:10.1029/2011PA002224, 2012.

Moore, P. D.: The future of cool temperate bogs, Environ. Conserv., 29, 3-20, 2002.

Morris, P. J., Belyea, L. R., and Baird, A. J.: Ecohydrological feedbacks in peatland development: a theoretical modeling study, J. Ecol., 99, 1190-1201, 2011.

Nilsson, M., Sagerfors, J., Buffam, I., Laudon, H., Eriksson, T., Grelle, A., Klemedtsson, L., Weslien, P., and Lindroth, A.: Contemporary carbon accumulation in a boreal oligotrophic minerogenic mire - A significant sink after accounting for all Cfluxes, Glob. Change Biol., 14, 2317-2332, doi:10.1111/j.13652486.2008.01654.x, 2008.

Post, W. M., Emanuel, W. R., Zinke, P. J., and Stangenberger, A. G.: Soil carbon pools and world life zones, Nature, 298, 156$159,1982$.

Oechel, W. C.: Nutrient and water flux in a small Arctic watershed: an overview, Holarctic Ecol., 12, 229-237, 1989. 
Olefeldt, D., Roulet, N. T., Bergeron, O., Crill, P., Bäckstrand, K., and Christensen, T. R.: Net carbon accumulation of a high-latitude permafrost palsa mire similar to permafrost-free peatlands, Geophys. Res. Lett., 39, L03501, doi:10.1029/2011GL050355, 2012.

Riley, J. L.: Peat and peatland resources of Northeastern Ontario, Ontario Geological Survey Miscellaneous Paper, 153, 1-155, 1994.

Riley, J. L.: Wetlands of the Hudson Bay Lowland: An Ontario Overview, Nature Conservancy of Canada, Toronto, ON, 156 pp., 2011.

Roulet, N. T.: Peatlands, carbon storage, greenhouse gases, and the Kyoto protocol: prospecs and significance for Canada, Wetlands, 20, 605-615, 2000.

Roulet, N. T., Lafleur, P. M., Richard, P. J. H., Moore, T. R., Humphreys, E. R., and Bubier, J.: Contemporary carbon balance and late Holocene carbon accumulation in a northern peatland, Glob. Change Biol., 13, 397-411, 2007.

Ruddiman, W. F., Kutzbach, J. E., and Vavrus, S. J.: Can natural or anthropogenic explanations of late-Holocene $\mathrm{CO}_{2}$ and $\mathrm{CH}_{4}$ increases be falsified?, Holocene, 21, 865-879, doi:10.1177/0959683610387172, 2011.

Schlesinger, W. H.: Carbon balance in terrestrial detritus, Annu. Rev. Ecol. Syst., 8, 51-81, 1977.

Schlesinger, W. H.: Soil organic matter: A source of atmospheric $\mathrm{CO}_{2}$, in: The role of terrestrial vegetation in the global carbon cycle, edited by: Woodwell, G. M., Wiley, New York, 111-127, 1984.

Schneider, J., Kutzbach, L., and Wilmking, M.: Carbon dioxide exchange fluxes of a boreal peatland over a complete growing season, Komi Republic, NW Russia, Biogeochemistry, doi:10.1007/s10533-011-9684-x, in press, 2012.

Sheng, Y., Smith, L. C., MacDonald, G. M., Kremenetski, K. V., Frey, K. E., Velichko, A. A., Lee, M., Beilman, D. W., and Dubinin, P.: A high-resolution GIS-based inventory of the West Siberian peat carbon pool, Global Biogeochem. Cy., 18, GB3004, doi:10.1029/2003GB002190, 2004.

Sjörs, H.: Peat on earth: multiple use or conservation, Ambio, 9, 303-308, 1980.

Sjörs, H.: The zonation of northern peatlands and their importance for the carbon balance of the atmosphere, Int. J. Ecol. Environ. Sci., 7, 11-14, 1981.

Smith, L. C., MacDonald, G. M., Velichko, A. A., Beilman, D. W., Borisova, O. K., Frey, K. E., Kremenetski, K. V., and Sheng, Y.: Siberian peatlands a net carbon sink and global methane source since the Early Holocene, Science, 303, 353-356, 2004.

St. Louis, V., Kelly, C., Duchemin, E., Rudd, J., and Rosenberg, D.: Reservoir surfaces as sources of greenhouse gases to the atmosphere: a global estimate, BioScience, 50, 766-775, 2000.

Sulman, B. N., Desai, A. R., Saliendra, N. Z., Lafleur, P. M., Flanagan, L. B., Sonnentag, O., Mackay, D. S., Barr, A. G., and van der Kamp, G.: $\mathrm{CO}_{2}$ fluxes at northern fens and bogs have opposite responses to inter- annual fluctuations in water table, Geophys. Res. Lett., 37, L19702, doi:10.1029/2010GL044018, 2010.

Syed, K. H., Flanagan, L. B., Carlson, P. J., Glenn, A. J., and van Gaalen, K. E.: Environmental control of net ecosystem $\mathrm{CO}_{2}$ exchange in a treed, moderately rich fen in northern Alberta, Agr. Forest Meteorol., 140, 97-114, 2006.
Tarnocai, C., Kettles, I. M., and Lacelle. B.: Peatlands of Canada, Ottawa, Agriculture and Agri-Food Canada, Research Branch, Ottawa, ON, Canada, 2005.

Tarnocai, C., Canadell, J. G., Schuur, E. A. G., Kuhry, P., Mazhitova, G., and Zimov, S.: Soil organic carbon pools in the northern circumpolar permafrost region, Global Biogeochem. Cy., 23, GB2023, doi:10.1029/2008GB003327, 2009.

Tarnocai, C., Kuhry, P., Broll, G., Ping, C.-L., and Brown, J.: Peatlands and their carbon dynamics: Comment on "Peatlands and their role in the global carbon cycle", Eos, 93, 31, 2012.

Tolonen, K. and Turunen, J.: Accumulation rates of carbon in mires in Finland and implications for climate change, Holocene, 6, 171-178, 1996.

Turetsky, M. R., Manning, S., and Wieder, R. K.: Dating recent peat deposits, Wetlands, 24, 324-356, 2004.

Turetsky, M. R., Kane, E. S., Harden, J. W., Ottmar, R. D., Manies, K. L., Hoy, E., and Kasischke, E. S.: Recent acceleration of biomass buring and carbon losses in Alaskan forest and peatlands, Nat. Geosci., 4, 27-31, 2011a.

Turetsky, M. R., Donahue, W. F., and Benscoter, B. W.: Experimental drying intensifies burning and carbon losses in a northern peatland, Nat. Commun., 2, 514, doi:10.1038/ncomms1523, 2011b.

Turunen, J., Tomppo, E., Tolonen, K., and Reinikainen, A.: Estimating carbon accumulation rates of undrained mires in Finland - application to boreal and subarctic regions, Holocene, 12, 6980, 2002.

van Bellen, S., Dallaire, P.-L., Garneau, M., and Bergeron, Y.: Quantifying spatial and temporal Holocene carbon accumulation in ombrotrophic peatlands of the Eastmain region, Quebec, Canada, Global Biogeochem. Cy., 25, GB2016, doi:10.1029/2010GB003877, 2011.

Vitt, D. H., Halsey, L. A., Bauer, I. E., and Campbell C.: Spatial and temporal trends in carbon storage of peatlands of continental western Canada through the Holocene, Can. J. Earth Sci., 37, 683-693, 2000.

Vitt, D. H., Halsey, L. A., and Nicholson, B. J.: The Mackenzie River basin, in: The World's Largest Wetlands: Ecology and Conservation, edited by: Fraser, L. H. and Keddy, P. A., Cambridge University Press, Cambridge, 166-202, 2005.

Waddington, J. M. and Roulet, N. T.: Carbon balance of a boreal patterned peatland, Glob. Change Biol., 6, 87-97, 2000.

Wieder, R. K.: Past, present and future peatland carbon balance An empirical model based on ${ }^{210} \mathrm{~Pb}$-dated cores, Ecol. Appl., 7 , 321-336, 2001.

Yefremov, S. P. and Yefremova, T. T.: Stocks and forms of deposited carbon and nitrogen in bog ecosystems of west Siberia, in: West Siberian Peatlands and Carbon Cycle: Past and Present, edited by: Vasiliev, S. V., Titlyanova, A. A., and Velichko, A. A., Agenstvo Sibprint, Novosibirsk, Russia, 148-151, 2001.

Yu, Z. C.: Holocene carbon accumulation of fen peatlands in boreal western Canada: Complex ecosystem response to climate variation and disturbance, Ecosystems, 9, 1278-1288, 2006.

Yu, Z. C.: Holocene carbon flux histories of the world's peatlands: Global carbon-cycle implications, Holocene, 21, 761-774, 2011.

Yu, Z. C., Beilman, D. W., and Jones, M. C.: Sensitivity of northern peatlands to Holocene climate change, in: Carbon Cycling in Northern Peatlands, edited by: Baird, A., Belyea, L., Comas, X., Reeve, A., and Slater, L., AGU, Geophys. Monog. Series, 184, 
55-69, doi:10.1029/2008GM000822, 2009.

Yu, Z. C., Loisel, J., Brosseau, D. P., Beilman, D. W., and Hunt, S. J.: Global peatland dynamics since the Last Glacial Maximum, Geophys. Res. Lett., 37, L13402, doi:10.1029/2010GL043584, 2010.

Yu, Z. C., Beilman, D. W., Frolking, S., MacDonald, G. M., Roulet, R. T., Camill, P., and Charman, D. J.: Peatlands and their role in the global carbon cycle, Eos, American Geophysical Union Transactions, 92, 97-98, 2011.

Yu, Z. C., Beilman, D. W., Frolking, S., MacDonald, G. M., Roulet, R. T., Camill, P., and Charman, D. J.: Peatlands as a model ecosystem of soil carbon dynamics: Reply to comment on "Peatlands and their role in the global carbon cycle", Eos, American Geophysical Union Transactions, 93, 31, 2012a.
Yu, Z. C., Loisel, J., Turetsky, M. R., Cai, S. S., Zhao, Y., Frolking, S., MacDonald, G. M., and Bubier, J. L.: Evidence for elevated emissions from high-latitude wetlands causing high atmospheric $\mathrm{CH}_{4}$ concentration in the early Holocene, in review, 2012b.

Zoltai, S. C.: Estimating the age of peat samples from their weight: a study from west-central Canada, Holocene, 1, 68-73, 1991.

Zoltai, S. C.: Cyclic development of permafrost in the peatlands of northwestern Alberta, Canada, Arctic Alpine Res., 25, 240-246, 1993.

Zoltai, S. C., Siltanen, R. M., and Johnson, R. D.: A wetland database for the western boreal, subarctic, and arctic regions of Canada, NOR-X-368, Canadian Forest Service, Northern Forestry Centre, Edmonton, AB, Canada, 2000. 